SHORT REPORT

\title{
A randomised study of the impact of different styles of patient information leaflets for randomised controlled trials on children's understanding
}

\author{
K Barnett, C Harrison, F Newman, C Bentley, C Cummins
}

Arch Dis Child 2005;90:364-366. doi: 10.1136/adc.2003.034041

T his study explores how the format of written information presented to children affects their understanding of the concepts behind randomised controlled trials (RCTs). Its aim was to identify whether this understanding could be increased by altering the style of information forms. We hypothesised that focusing information in a question and answer format, or presenting concepts as a story, would lead to a greater understanding than is achieved by the traditional block text format. If this proved successful, researchers could have more confidence that a child's consent was informed. The Department of Health ${ }^{1}$ upholds the concept of Gillick competence for research purposes and recommends that "appropriately designed information should be available for children involved in research". The aim is to allow children to develop competence ${ }^{1}$ in giving informed consent, which is necessary to protect children's rights. ${ }^{2}$ Improved written patient information would mean research involving children could be undertaken with more confidence, leading to increased participation of children in RCTs.

\section{PARTICIPANTS, METHODS, AND RESULTS}

A total of 374 school children aged 9-11, from seven different schools, participated. The design used was a piloted comparative intervention study, conducted in the classroom environment. Based on a standardised scenario, information leaflets in the three aforementioned styles were composed, ensuring comparable readability. A questionnaire was devised, consisting of 12 randomly ordered questions requiring a yes/no/don't know response. These questions aimed to test children's understanding of four of the concepts considered essential for inclusion in adult information forms: randomisation (example question and answer: If I take part in the test I can pick which medicine I take, no); safety and effectiveness (example question and correct answer: Medicine B will definitely make me better, no); voluntariness (example question and correct answer: The doctor will treat me even if I don't take part in his test, yes); and avenues of redress (example question and correct answer: If something goes wrong, the doctor could be told off, yes). There were three questions for each concept. The number getting all three answers correct was analysed. This was to ensure that the children truly understood, and to reduce the possibility that they were guessing. Questions were also asked about whether the children found the forms easy to read, and if they would help the doctor, as well as allowing them to make any other comments. The information leaflets were randomly distributed to the children who then completed the questionnaires (fig 1). Every effort was made to standardise the method between schools, and to avoid interviewer bias. The study was approved by the South Birmingham Research Ethics Committee.

Table 1 shows the number of children who answered all three questions in a category correctly. For all the categories except voluntariness the story has the highest number of children in this group.

The story was found to be significantly better at enabling the children to understand the unknown effectiveness of "medicine B", and in conveying that participation in this study is voluntary (table 1). A strong but non-significant trend showed that the story was better than the question and answer form at explaining the concept of randomisation.

The numbers of questions answered correctly for each format of leaflet were compared. The story format was the most understandable and the question and answer format was least understandable ( $t$ test, $\mathrm{p}<0.001$ ).

Fifty eight per cent of children said they would help the doctor after reading the story format, compared to $71 \%$ who read the block text, and $72 \%$ who read the question and answer format. There was no significant difference of the reported ease of reading between the formats.

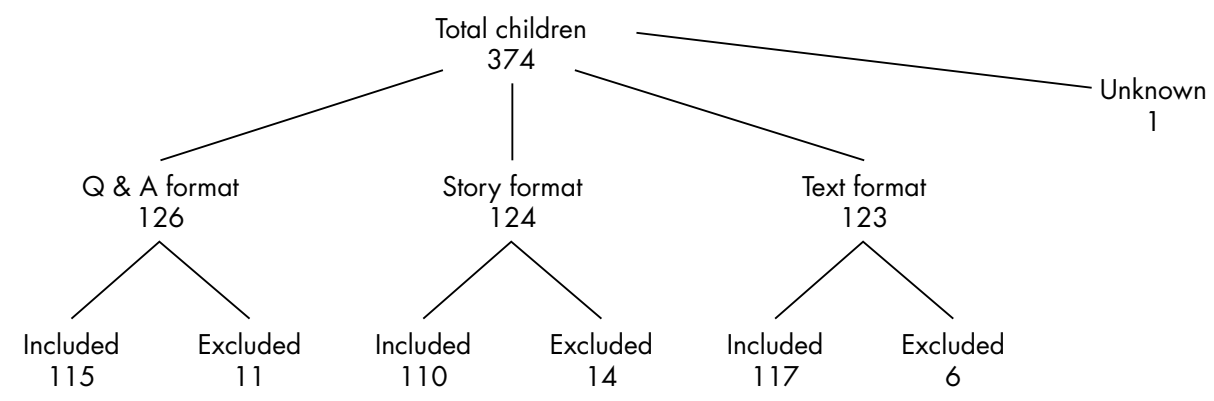

Figure 1 Allocation of patient information leaflets in different formats.

Excluded $=$ excluded because English was not confirmed to be their first language

Unknown $=$ this child failed to write the form number on their answer sheet and was therefore excluded 
Table 1 Number and percentage of children replying correctly, incorrectly, or not knowing the answer to each question

\begin{tabular}{|c|c|c|c|c|c|c|c|c|c|}
\hline \multirow[b]{2}{*}{ Questions } & \multicolumn{3}{|c|}{ Question and answer format } & \multicolumn{3}{|c|}{ Story format } & \multicolumn{3}{|c|}{ Block text format } \\
\hline & $\begin{array}{l}\text { Correct } \\
\text { answer }\end{array}$ & $\begin{array}{l}\text { Incorrect } \\
\text { answer }\end{array}$ & Don't know & $\begin{array}{l}\text { Correct } \\
\text { answer }\end{array}$ & $\begin{array}{l}\text { Incorrect } \\
\text { answer }\end{array}$ & Don't know & $\begin{array}{l}\text { Correct } \\
\text { answer }\end{array}$ & $\begin{array}{l}\text { Incorrect } \\
\text { answer }\end{array}$ & Don't know \\
\hline $\begin{array}{l}\text { Concept of randomisation } \\
\text { If I take part in the test, }\end{array}$ & 71 (62\%) & $23(20 \%)$ & $21(18 \%)$ & $68(62 \%)$ & $19(17 \%)$ & $23(21 \%)$ & $76(65 \%)$ & $18(15 \%)$ & $15(13 \%)$ \\
\hline medicine I get & & & & & & & & & \\
\hline $\begin{array}{l}\text { The doctor will always } \\
\text { give me the best medicine }\end{array}$ & $39(34 \%)$ & $57(50 \%)$ & $19(17 \%)$ & $43(39 \%)$ & $53(48 \%)$ & $14(13 \%)$ & $52(44 \%)$ & $43(37 \%)$ & $22(19 \%)$ \\
\hline $\begin{array}{l}\text { If I take part in the test } \\
\text { I can pick which medicine }\end{array}$ & $88(77 \%)$ & $17(15 \%)$ & $10(9 \%)$ & $84(76 \%)$ & $20(18 \%)$ & $6(5 \%)$ & $87(74 \%)$ & $23(20 \%)$ & $7(6 \%)$ \\
\hline $\begin{array}{l}\text { No. of children getting } \\
\text { all three answers correct* }\end{array}$ & $8(7 \%)$ & & & $23(21 \%)$ & & & $15(13 \%)$ & & \\
\hline \multicolumn{10}{|l|}{ Unknown effect of medicine B } \\
\hline $\begin{array}{l}\text { There is a chance that } \\
\text { medicine B will make } \\
\text { me feel sick or sleepy }\end{array}$ & $98(85 \%)$ & $8(7 \%)$ & $9(8 \%)$ & $77(70 \%)$ & $18(16 \%)$ & $15(14 \%)$ & $94(80 \%)$ & $8(7 \%)$ & $15(13 \%)$ \\
\hline $\begin{array}{l}\text { The doctor does not } \\
\text { know what medicine } \\
\text { B will do }\end{array}$ & $63(55 \%)$ & $36(31 \%)$ & $16(14 \%)$ & $64(58 \%)$ & $31(28 \%)$ & $15(14 \%)$ & $71(61 \%)$ & $36(31 \%)$ & $10(9 \%)$ \\
\hline Medicine B will & $57(50 \%)$ & $13(11 \%)$ & $45(39 \%)$ & $63(57 \%)$ & $20(18 \%)$ & $27(35 \%)$ & $73(62 \%)$ & $4(3 \%)$ & $40(34 \%)$ \\
\hline $\begin{array}{l}\text { No. of children getting } \\
\text { all three answers correct*** }\end{array}$ & $8(7 \%)$ & & & $36(33 \%)$ & & & $17(15 \%)$ & & \\
\hline \multicolumn{10}{|l|}{ Voluntariness } \\
\hline $\begin{array}{l}\text { The doctor will not treat } \\
\text { me if I do not take part } \\
\text { in his trial }\end{array}$ & $77(67 \%)$ & $30(26 \%)$ & $8(7 \%)$ & $73(66 \%)$ & $21(19 \%)$ & $16(15 \%)$ & $84(72 \%)$ & $18(15 \%)$ & $15(13 \%)$ \\
\hline $\begin{array}{l}\text { I have to take part in the } \\
\text { doctor's test }\end{array}$ & 107 (93\%) & $6(5 \%)$ & $2(2 \%)$ & $94(85 \%)$ & $7(6 \%)$ & $9(8 \%)$ & $106(91 \%)$ & $8(7 \%)$ & $3(3 \%)$ \\
\hline $\begin{array}{l}\text { The doctor will treat } \\
\text { me even if I don't take } \\
\text { part in his test }\end{array}$ & 88 (77\%) & $17(15 \%)$ & $10(9 \%)$ & $79(72 \%)$ & $20(18 \%)$ & $11(10 \%)$ & $94(80 \%)$ & 18 (15\%) & $5(4 \%)$ \\
\hline $\begin{array}{l}\text { No. of children getting } \\
\text { all three answers } \\
\text { correct* }^{*}\end{array}$ & $11(10 \%)$ & & & 11 (10\%) & & & $16(14 \%)$ & & \\
\hline \multicolumn{10}{|l|}{ Avenues of redress } \\
\hline $\begin{array}{l}\text { If something goes } \\
\text { wrong, it cannot be the } \\
\text { doctor's fault }\end{array}$ & 64 (56\%) & $37(32 \%)$ & 14 (12\%) & 51 (46\%) & $43(39 \%)$ & $16(15 \%)$ & 78 (67\%) & $32(27 \%)$ & $7(6 \%)$ \\
\hline $\begin{array}{l}\text { If something goes } \\
\text { wrong, the doctor could } \\
\text { be told off }\end{array}$ & $104(90 \%)$ & $8(7 \%)$ & $3(3 \%)$ & 95 (86\%) & $10(9 \%)$ & $5(5 \%)$ & $107(91 \%)$ & $8(7 \%)$ & $2(3 \%)$ \\
\hline $\begin{array}{l}\text { If the doctor hurts me, } \\
\text { I cannot do anything } \\
\text { about it }\end{array}$ & $65(57 \%)$ & $35(30 \%)$ & $15(13 \%)$ & $58(53 \%)$ & $36(33 \%)$ & $16(15 \%)$ & $68(58 \%)$ & $32(27 \%)$ & $17(15 \%)$ \\
\hline $\begin{array}{l}\text { No. of children getting } \\
\text { all three answers } \\
\text { correct*** }\end{array}$ & $26(23 \%)$ & & & $56(51 \%)$ & & & $24(21 \%)$ & & \\
\hline
\end{tabular}

\section{COMMENT}

This study proved that it is possible to improve children's understanding by altering the format of the information leaflet. The story format was clearly superior in maximising children's understanding. This is perhaps because it is a format with which children are more familiar. Interestingly those who read the story were less inclined to help the doctor. This might be a chance finding or a result of the children's better comprehension: factors encouraging or discouraging children from participation in research should be included in further research. This study also showed that children are capable of understanding information leaflets without verbal explanation, with success ranging from 6.54 to 7.52 questions answered correctly out of a possible 12. Thus written information has an important independent contribution in obtaining informed consent from children. It is likely that understanding could be further improved by additional verbal explanation and by illustrating leaflets.
It should be noted that the sample was likely to have higher than average educational achievement: $89 \%$ of children at the schools sampled had gained level 4 or greater in their key stage 2 SATS compared to the national average of $75 \%$. The sample's higher than average comprehension skills may have helped in their understanding of the leaflets, but whether their greater educational achievement and probable higher than average social status would mean they were more likely than average to consent take part in clinical studies is unknown. How the understanding of children with poorer educational achievement can be improved should be the target of further research. A limitation of this study is that some of the questions used to test the children's understanding were reported to be difficult to read, thus development of an improved questionnaire would facilitate further studies. There is little research in this area but the findings of this study indicate that further research into how written information can facilitate children's understanding of 
clinical studies could assist in the practical implementation of the Department of Health's guidelines in seeking consent in the paediatric setting. ${ }^{3}$

\section{ACKNOWLEDGEMENTS}

This study was completed as part of a special study module of the Birmingham University MBBS course.

Supplementary material (leaflets and questionnaire) is available on the Archives of Disease in Childhood website (www.archdischild.com/supplemental)

\section{Authors' affiliations}

K Barnett, C Harrison, F Newman, C Bentley, The Medical School, University of Birmingham, Edgbaston, Birmingham, UK
C Cummins, Institute of Child Health, Whittall Street, Birmingham, UK

Competing interests: none declared

Correspondence to: $\operatorname{Dr} C$ Cummins, Institute of Child Health, Whittall Street, Birmingham B4 6NH, UK; c.l.cummins@bham.ac.uk

Accepted 21 August 2004

\section{REFERENCES}

1 Department of Health. Reference guide to consent for examination or treatment. London: The Stationary Office, 2001 (www.doh.gov.uk; accessed 17 December 2001).

2 World Medical Association. The Declaration of Helsinki. Ferney-Voltaire, France: The Association, 1996.

3 Department of Health. Seeking consent: working with children. London: The Stationary Office, 2001 (www.doh.gov.uk/consent; accessed 20 October 2002).

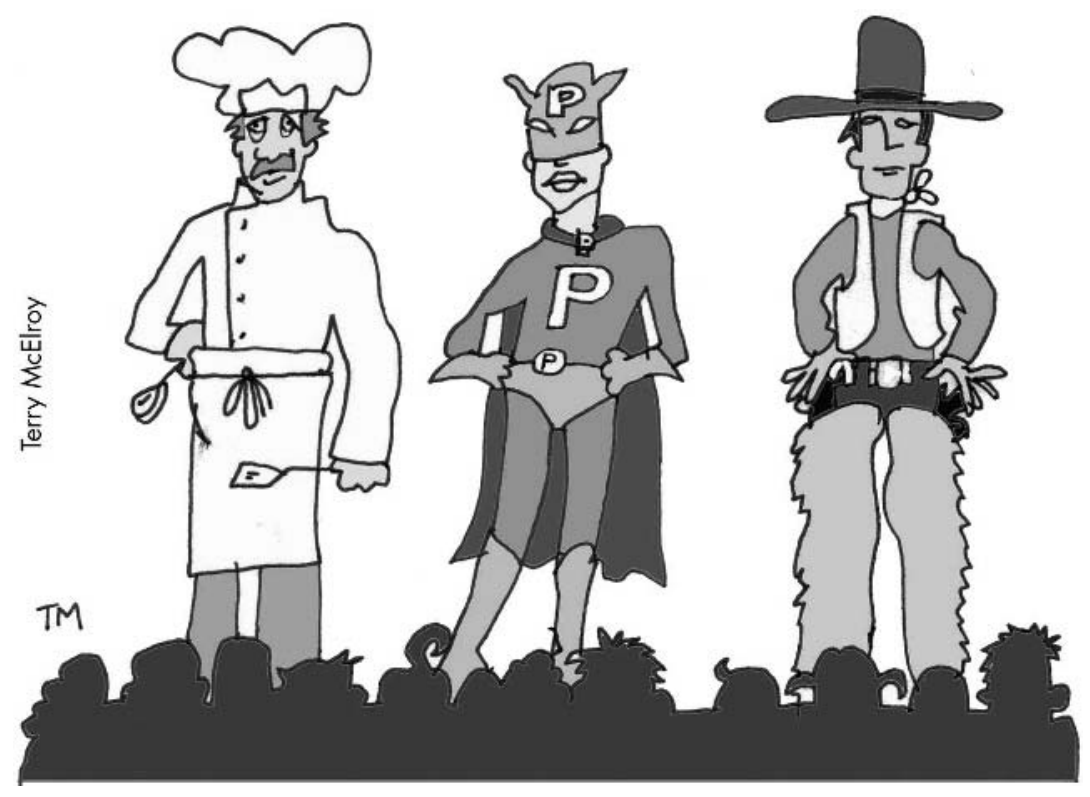

